\title{
Yogyakarta Modernity Dynamics: A Study of Code-Switching in Kedaulatan Rakyat's Weekly Short Stories from 2010 to 2015
}

\author{
Fransisca Kristanti \\ f.kristanti@usd.ac.id \\ English Letters Department, Universitas Sanata Dharma
}

\begin{abstract}
This research analyzes how language reflects Yogyakarta modernity dynamics through the analysis of Kedaulatan Rakyat's weekly short stories from 2010 to 2015. The research is aimed to find out how the city's modernity is portrayed through language by the means of code-switching in the weekly short stories. It identifies the phenomena of code-switching in the short stories and analyzes whether or not the switch is an illustration of the city's modernity through language.
\end{abstract}

Keywords: code-switch, short stories, modernity, Yogyakarta.

\section{Introduction}

Language shapes society and vice versa. The way the society uses a language illustrates their way of living. Sociologically, the society's character is limited by the language they use. The more items exist in one's society 'wardrobe', the more elaborative they can refer the world they live in. One might argue that the constraint of the language expressions exists within the language itself, not the society. One group of people might have the ability of referring to the world by a combination of some languages (or dialects).

Globalization thought of the idea of having one language in one society to be obsolete. It demands people to be able to perform inter-communal communication in the midst of the present contemporary community, leading to the emergence of the 'global' community. In this era, boundaries are no longer marked by the nation's imaginary borders, as argued by Anderson (2006), nor by race. Globalization requires people to survive by the degree of their ability in communicating cross-codes, crosslanguages.

The general concept of globalization imbeds most areas in the world, if not all, Yogyakarta included. The atmosphere of globalization is vividly present in Yogyakarta, especially in the past years. Right after the Mount Merapi eruption in 2010, the city set its heart to rebuild its infrastructure for its people. However, the sense of being a member of the global community seems to have a very strong grip on the city's stake holders and decision makers. It is visible that Yogyakarta sets its heart to be the city of travel industry. The city has been preparing itself for this goal by undergoing urbanization processes for the past years. These processes were marked by the massive infrastructure development.

Along with the massive infrastructure development, Yogyakarta's determination to become the city of tourism industry also calls for the people's mastery of English 
alongside their mother tongue and Indonesian language. By opening the city to embrace International community, the mastery of English is no longer an option. It becomes a necessity. However, as the city of culture, the Yogyakarta's elderly holds strongly to the practice of Javanese language. By this, the culture is more or less preserved. On the other hand, the driving forces of the tourism industry are mostly those who are in their productive age. Even though the ones in their productive age use Javanese and Indonesian language in their daily communication, more and more people of Yogyakarta use English.

As the city progresses physically, more and more young people are familiar with English. English terminologies have become widely used in communication among people. A part of the reason is because of the number of expatriates and foreign students who stay in Yogyakarta intrigues those who interact with them to exercise English. Moreover, being the city which undergoes changes to become the city of tourism industry, Yogyakarta welcomes local and International tourists, which means that Indonesian and English become the language of the city in this particular context.

The fundamental idea of this research is to find out whether language choice reflects modernity. However, considering that Yogyakarta is a multicultural city, the object of the study attempts to focus to the people embracing the culture of the city. Kedaulatan Rakyat, a local newspaper, is an excellent example of documentation about the culture of Yogyakarta. Kedaulatan Rakyat is placed in the heart of Yogyakarta. Established in 1945, the newspaper soon became one of the biggest newspaper in Yogyakarta. The ability to stand the test of time for more than 70 years makes the newspaper becomes an integrated culture of Yogyakarta.

This research focuses on the short stories published weekly in the newspaper. Eagleton (1983) states that literature illustrates the way the society functions. It is a reflection of a particular society in different functions, from religious to political functions. He also states that literature can be considered to be a description of history specifically.

Therefore, this research explores language expressions used in the weekly short stories which portray the modernity dynamics happening in Yogyakarta. By identifying the language expressions existed in the texts, this research attempts to draw a conclusion whether or not the modernity dynamics is reflected in the Kedaulatan Rakyat's weekly short stories within the sixyear duration, starting from 2010, the time of the historical Mount Merapi eruption.

\section{Code-switching}

Code-switching is defined as the use of two codes alternatively among the people who have shared knowledge of the languages. Weinreich (1968) defines codeswitching as a sub-standard practice of the phenomenon of switching from one language to the other among bilingual people based on the context they were in. However, modern linguistic research finds code-switching to be systematic and it follows certain pattern which is meaningful in language use. Bullock and Toribio (2009) refers code-switching as the alternation between two codes (languages) which happens spontaneously within the same discourse. This is supported by Haugen's (1956) statement about the introduction of a "completely unassimilated word from another language" (40) when someone is speaking.

Bilingual speakers practice codeswitching not only to smoothen conversation, but also to eliminate ethnic boundaries as well as identities. Heller (1988) argues that in social process, codeswitching enables multilinguals to use "a resource for indexing situationally salient aspects of context in speaker's attempts to accomplish interactional goals" (3). Context is important in the realization of codeswitching. The switch might take many forms between languages. Skiba (1997) mentions that code-switching can be realized in many forms, from the alternation 
of sentences to the alternation of words from both codes. Furthermore, Myers-Scotton (1993) states that code-switching is "the selection by bilinguals or multilinguals of forms from an embedded variety (or varieties) in utterances of matrix variety during the same conversation" (3).

\section{Factors of Code-switching}

Code-switching is motivated by many factors, among which are the linguistic factors and the social factors. Gumperz (1982) states that multilinguals utilize codeswitching to express meanings in social context depending on the situation as well as other variables. Furthermore, he claims that some linguistic limitations and social aspects motivates the switch to take place.

Linguistic factors of the code-switch refers to the grammatical aspects of the languages. In this area, code-switching can take place within sentences or between sentences. Within the context of linguistic factors, code-switching happens when words, phrases, or sentences from different languages which have different linguistic structures without any sentence limitation occur in a single statement (Myers-Scotton, 1997).

On the other hand, social factors and dimensions are the determining aspects of the choice to use a particular language instead of the others. Social factors are responsible for the occurrence of various sociolinguistic phenomena such as codeswitching. The determining aspects of social factors are elaborated into context, participants, topic, and purpose (Holmes, 2013). This particular research considers the authors, not the characters, in the short stories as the participants. The authors speak to the readers using the characters, thus the choice of language falls to the author. The set of the context is the authors as a member of Yogyakarta's community who are tangled in the city's issues and use their short stories to address the issues which becomes their concerns. Topics are not limited in certain discourses due to the necessity of analyzing all types of discourses brought up in the short stories.

People code-switch for various reasons due to the attainment of certain targets. Reasons for code-switching has been studied by many linguists over the years. Appel and Muysken (2006) lists six basic functions of code-switching based on the previous notions presented by Halliday et al. (1964) namely referential function, directive function, expressive function, phatic function, metalinguistic function, and poetic function.

The referential function is based on the lack reference of a certain language. When bilingual needs to refer to a particular word using a certain language, he/she needs to consider the context and concept of the words. It is very common that the vocabulary of a certain language does not carry the concept which needs to be conveyed. The speaker then has to switch code to the language which expresses the concept most appropriately.

Directive function is based on whether or not the speaker decides to include or exclude specific participants from the conversation. The speaker has the ability of using the terminology from a language which is familiar to the person when he/she decides to include the person. On the other hand, if the speaker decides to exclude the person from a conversation, he/she will use the terminology from a language which is foreign to the person.

Expressive function illustrates the speaker's needs to highlight his/her identity or feelings towards others participating in the conversation. The speaker switch codes to emphasize his/her feelings. Phatic function highlights the importance of certain parts in the conversation. The speaker use code-switches to emphasize the parts of the conversation which are important. Metalinguistic function occurs when the speaker chooses to comment a particular feature of a language by using another language. Finally, poetic function occurs when a speaker chooses to code-switch for the sake of entertainment as when he/she 
uses puns or making jokes, then he/she applies the poetic function of the codeswitching.

Moreover, in the sociolinguistic discussion of code-switching by Malik (1994) about the code-switching phenomenon happening in India, reasons for the code-switching are presented. First, people code-switch because of lacking facility. Bilinguals switch code when certain concepts in one language are not available in the other. The switch is intended to avoid misconception and misunderstanding due to the loss in translation. Second, people codeswitch because lacking registral competence. Bilinguals who are competent in a language and not as equally competent in other language are common. These bilinguals code-switch because they find difficulties in selecting appropriate vocabularies in their non-mother tongue for a specific discourse.

Third, people code-switch because of their mood change. People are in constant mood change. When bilinguals code-switch based on their mood they tend to do that because the one they choose to use takes less effort and time. The expression itself might be present in both languages. Fourth, people code-switch to amplify and emphasize a point. The code-switching happens when the bilinguals decides to highlight a point in the speech. This might happen during arguments or presentations.

Fifth, people code-switch because of habitual expressions. Some fixes phrases such as instructions, orders, apologies, and other discourse markers are common practice of code-switching. The codeswitching may elevate or reduce the strength of the speech. Seven, people codeswitch because of the presence of semantic significance. Bilinguals switch codes to convey important information linguistically and socially. This is used as a verbal strategy. Finally, people code-switch to show identity with a group. Code-switching is a common practice to mark shared values by the people of the same culture. The preservation of a certain words and phrases in their original language is used to highlight a sense of belonging within the group.

\section{Data Collection and Analysis}

This is a preliminary research targeting on the identification of code-switching in Kedaulatan Rakyat's weekly short stories published from 2010 to 2015 in order to see the tendency of Yogyakarta's citizen in using English as the mark of the city's modernization. 224 short stories published in Kedaulatan Rakyat from January 2010 to April 2015 were collected to be analyzed. After the short stories were collected, identification of code-switch from Indonesian language to others were done. Then reasons behind the code-switching to each language is analyzed by applying the arguments from Malik (1994) and Appel and Muysken (2006), the occurrence in each switching language is compared. From the findings, a conclusion on whether or not the code-switch occurring in the short stories illustrates the modernity dynamics in Yogyakarta were made.

\section{Findings and Discussion}

Code-switching occurs in 101 out of 224 short stories $(42 \%$ of the overall short stories). The occurrence of the switch varies in number, in codes, and in structures. The switch in one short story are mostly targeting one code, yet there are some short stories which contain multiple-code switch. Nineteen short stories contain multiple-code switch. The distribution of between the single-code switch and the multiple-code switch is presented in Table 1. 
Table 1

Distribution of Short Stories with Single-code Switch and Double-code Switch

\begin{tabular}{|c|c|c|c|l|}
\hline Year & Total & SC & MC & Switch to (from most to least) \\
\hline 2010 & 25 & $72 \%$ & $28 \%$ & Javanese, English, Arabic, French \\
\hline 2011 & 21 & $86 \%$ & $14 \%$ & Javanese, English, Padangnese \\
\hline 2012 & 15 & $60 \%$ & $40 \%$ & Javanese, English, Arabic, Japanese \\
\hline 2013 & 19 & $84 \%$ & $16 \%$ & Javanese, English, Japanese \\
\hline 2014 & 16 & $94 \%$ & $6 \%$ & Javanese, English, Arabic, French \\
\hline 2015 & 5 & $100 \%$ & $0 \%$ & Javanese, English \\
\hline Total & 101 & $\mathbf{8 3} \%$ & $\mathbf{1 7} \%$ & \\
\hline
\end{tabular}

Description

Total: the total number of the short stories containing code-switching within the year;

SC: the number of short stories containing single-code switch within the year;

$M C$ : the number of short stories containing multiple-code switch within the year.

From the overall data, $83 \%$ of the short stories contain single-code switch, whereas only $17 \%$ contain multiple-code switch. The multiple-code switch all contain double-code switch which is the combination of Javanese and another code. The findings illustrate the preservation of the Yogyakarta's culture since the code shifts from Indonesian to Javanese. Overall, the data show that the original code (Indonesian) switch to six different codes, namely: Javanese, English, Arabic, Japanese, French, and Padangnese. The distribution of each code is described in Table 2.

Table 2

Distribution of Codes

\begin{tabular}{|l|c|c|c|c|c|c|c|}
\hline \multirow{2}{*}{ Year } & $\begin{array}{c}\text { Total } \\
\text { number } \\
\text { of code- } \\
\text { switch }\end{array}$ & \multicolumn{6}{|l|}{ Occurrence of code-switch from Indonesian to } \\
\cline { 3 - 8 } & English & French & Arabic & Japanese & Javanese & Padangnese \\
\hline 2010 & 58 & 17 & 2 & 5 & 0 & 34 & 0 \\
\hline 2011 & 71 & 15 & 0 & 0 & 0 & 54 & 2 \\
\hline 2012 & 56 & 16 & 0 & 11 & 10 & 19 & 0 \\
\hline 2013 & 68 & 17 & 0 & 0 & 8 & 43 & 0 \\
\hline 2014 & 32 & 11 & 2 & 2 & 0 & 17 & 0 \\
\hline 2015 & 6 & 2 & 0 & 0 & 0 & 4 & 0 \\
\hline TOTAL & 291 & 78 & 4 & 18 & 18 & 171 & 2 \\
\hline$\%$ & 100 & 26.8 & 1.4 & $\mathbf{6 . 2}$ & $\mathbf{6 . 2}$ & 58.8 & 0.7 \\
\hline
\end{tabular}

Table 2 shows that Javanese holds the highest number of the code being shifted to. The languages which are consistently occurring in the code-shift phenomena from
Indonesian are Javanese and English. In 2010, Javanese occurred twice as many as the English. In 2011, Indonesian switched exclusively to English and Javanese, with the 
number of Javanese use more than three times of English use. In 2012, the trend was slightly changed by having almost equal distribution among four target languages: Javanese, English, Arabic, and Japanese. The trend came back in 2013 and lasted until 2015 where Javanese became the most used switched language.

The findings show that even though the switch to English is quite significant, the switch to Javanese is more than double that of English. The English vocabularies occurring in the shift were those which are commonly used to refer to concepts. The English words occurring in the short stories are the ones which are very familiar to the Indonesians. The examples of the terminologies are trance, launching, soft drink, quick count, intellectual quotient, support, talk show, makeup, sound system, teleconference, breaking news, update, boarding, delay, check out, debt collector, valet parking, playgirl, meeting, dashboard, broken home, headline, off the record, bully, and trending topic.

The English words listed above are mostly used to retain the integrity of the concept they carry. The lack of facility of the Indonesian language to convey the particular concepts embedded in the English words becomes the main reason for this switch. Since the English words used in the short stories are those which have been used by the Indonesians in general, whether formally or informally, the switches do not happen due to the modernity dynamics within the six-year period. They have been frequently used long before 2010 .

On top of that, the English terminologies are used because they are considered as habitual expressions. The terminology of 'broken home' and 'makeup' have been used for decades in Indonesia. Moreover, aviation-specific terminology such as 'boarding' and 'delay' have been used in Indonesian airports from the get go. Therefore, the occurrence of code-switching to English from Indonesian in Kedaulatan Rakyat's weekly short stories from 2010 to 2015 does not illustrates the process of modernization of the people of Yogyakarta. It is purely chosen for their referential function.

The switch from Indonesian to Javanese, however, shows that the people of Yogyakarta are still strongly rooted to their tradition and culture through the means of language. First and foremost, Javanese in the short stories is used to highlight the sense of belonging within a group. It shows solidarity which portrays close kinship with the group. Malik (1994) refers to this as showing identity with a group. Words such as nduk, $l e$, guyub, and sim bah are good examples for this reason. Second, people use Javanese in regards to their mood change. Some expressions such as munyuk, ngeyel, ndesa, and ha mbok are shorter and more expressive than their Indonesian counterparts. Third, people code-switch to Javanese because of lacking facilities in Indonesian. Most Javanese words are untranslatable so when the speaker tries to use the words with the most similar meanings in Indonesian, they often got lost in translation. Words such as konthalkanthil, gremengan, gadhulan, nyeleneh, ewer-ewer, mengelesot, ongkang-ongkang, and gedebog contain specific concept which will not be retained in other codes.

Thus, it is fair to say that people codeswitch from Indonesian to Javanese mostly because of their referential and expressive functions. The code-switch serves extremely well to maintain original concept and expressive enough to convey emotion.

\section{Conclusion}

Considering the findings, codeswitching occurs sufficiently in Kedaulatan Rakyat's weekly short stories from 2010 to 2015. However, the code-switch does not portray the dynamics of modernity of the Yogyakarta's people. Instead of switching to English as the global language, the data show that the switch to Javanese happens more often. From this, it can be concluded that the people of Yogyakarta are still comfortable in their own culture. Unlike the massive infrastructure development which 
disregards the city's culture, the people highly consider Yogyakarta's culture by preserving it through language use.

\section{References}

Anderson, Benedict. Imagined Communities, Reflection on the Origin and Spread of Nationalism. Revised ed. London: Verso, 2006.

Appel, Rene and Pieter Muysken. Language Contact and Bilingualism. Amsterdam: Amsterdam University Press, 2006.

Bullock, Barbara E. and Almeida Jacqueline Toribio. 2009. "Themes in the study of code-switching" in Barbara E. Bullock and Almeida Jacqueline Toribio (Eds.) The Cambridge Handbook of Linguistic Code-switching. Cambridge: Cambridge University Press.

Eagleton, Terry. Literary Theory: An Introduction. Oxford: Blackwell Publishers, 1983

Gumperz, John J. Discourse Strategies. Cambridge: Cambridge University Press, 1982.

Haugen. The Norwegian Language in America. Vol. 2. Philadelphia: The University of Pennsylvania Press, 1953.

Heller, Monica. Codeswitching: Anthropological and Sociolinguistic Perspectives. Berlin: Mouton de Gruyter, 1988.

Holmes, Janet. An Introduction to Sociolinguistics. New York: Longman, 2013.

Malik, Lalita. Sociolinguistics: A Study of Code-switching. New Delhi: Anmol, 1994.
Myers-Scotton, Carol. Dueling Languages: Grammatical Structure in Codeswitching. Oxford: Oxford University Press, 1997.

Skiba, Richard. 1997. "Code Switching as a Countenance of Language Interference Unclassified Material. Internet TESL Journal. Retrieved from <iteslj.org> on 8 August 2015.

Weinreich, Uriel. Languages in Contact: Findings and Problems. New York: Linguistic Circle of New York, 1953.

Club. Harold Bloom (Ed.). Philadelphia: Chelsea House Publisher. 2003. 